\title{
Effects on empathy and emotional intelligence of a Teaching Personal and Social Responsibility programme in physical education \\ Efectos de un programa de Responsabilidad Personal y Social sobre la empatía y la inteligencia emocional en educación física
}

\author{
*Pablo Pozo Rosado, **Alberto Grao-Cruces, ***Ester Ayllon-Negrillo, ***Raquel Pérez-Ordás \\ *C.P.C. Antonio Machado (Sevilla, España), **Universidad de Cádiz (España), ***Universidad de Zaragoza (España)
}

\begin{abstract}
In recent years, research has pointed to the value of positive youth development programmes through physical education. The influence of this type of programme, specifically the Teaching Personal and Social Responsibility programme, on the empathy and emotional intelligence of students is a field to be explored. The study's aims were: (1) to investigate the effects of a Teaching Personal and Social Responsibility-based programme on empathy and perceived emotional intelligence in physical education; and (2) to compare the scores between lower-middle and upper-middle socioeconomic context schools. Participants were 210 students (ages 10-12). A quasi-experimental design with two analyses of covariance were completed. The programme improved the students' feelings of sadness $(\mathrm{p}<.05)$. More pronounced improvements were found on the feelings of sadness $(p=.016)$ in the lower-middle socioeconomic context group. The intervention was more effective on understanding feelings $(p<.001)$ in the upper-middle context group. Improvements were found in emotional intelligence $(p=.017)$, attention $(p<.05)$ and repair $(p<.026)$ factors in the lower-middle context group compared to the upper-middle context group. We found that the programme has been especially useful for improving emotional intelligence in depressed socioeconomic contexts.
\end{abstract}

Keywords: intervention, positive youth development, preadolescents, socioeconomic status, gender differences.

Resumen. En los últimos años, la investigación ha señalado el valor de los programas de desarrollo positivo adolescente a través de la educación física. La influencia de este tipo de programas, en concreto del programa de Enseñanza de la Responsabilidad Personal y Social, sobre la empatía y la inteligencia emocional de los alumnos es un campo por explorar. Los objetivos del estudio fueron: (1) investigar los efectos de un programa basado en el modelo de Enseñanza de Responsabilidad Personal y Social sobre la empatía y la inteligencia emocional percibida en educación física; y (2) comparar los resultados entre los colegios de contexto socioeconómico medio-bajo y medio-alto. Los participantes fueron 210 alumnos (de 10 a 12 años). Se realizó un diseño cuasi-experimental con dos análisis de covarianza. El programa mejoró los sentimientos de tristeza de los estudiantes $(\mathrm{p}<.05)$. Se encontraron mejoras más pronunciadas en los sentimientos de tristeza $(\mathrm{p}=.016)$ en el grupo de contexto socioeconómico medio-bajo. La intervención fue más efectiva en la comprensión de sentimientos $(\mathrm{p}<.001)$ en el grupo de contexto medio-alto. Se encontraron mejoras en los factores de inteligencia emocional $(\mathrm{p}=.017)$, atención $(\mathrm{p}$ $<.05)$ y reparación $(\mathrm{p}<.026)$ en el grupo de contexto medio-bajo en comparación con el grupo de contexto medio-alto. Encontramos que el programa ha sido especialmente útil para mejorar la inteligencia emocional en contextos socioeconómicos vulnerables.

Palabras clave: intervención, desarrollo positivo adolescente, preadolescentes, estatus socioeconómico, diferencias de género.

\section{Introduction}

Emotional development in children is drawing attention in the educational community (Bosacki, 2008; Macklem, 2011). Schools have a strong effect on children's emotional well-being, and, as they are an ideal environment to foster students' emotional learning and empathy, failing to optimize the opportunity to do so could impact society in negative

Fecha recepción: 11-08-21. Fecha de aceptación: 20-11-21

Pablo Pozo Rosado

pablo.pozros@gmail.com ways (Bywater \& Sharples, 2012; Jacobs, Knoppers, \& Webb, 2013). Today, there are many voices that claim to the school a priority role in the socio-emotional training of the students, related to the enhancement of competences that allow young people to make their contribution to community, and confront successfully their personal and professional life (Martinek \& Hellison, 2016).

In the field of social and emotional development, empathy has been identified by several authors as a fundamental resource for positive youth development. Empathy can be defined as «an affective response of understanding over the emotional state of others, which 
induces feeling the state in which the other is» (Eisenberg et al., 2010). As Garaigordobil and García (2006) stated, empathy include, on the part of the subject, both emotional responses and the ability to understand the affective states of others, which means carrying out a cognitive elaboration. At present, low emotional empathy is directly related to the violent and antisocial behaviours of the subjects, not being able to be apprehensive or understand the emotional state of the other subject, which leads to act aggressively in social contexts, especially in the school context (GómezSánchez et al., 2019; Stormont, 2002).

Another key resource in the development of children and young people is emotional intelligence (EI). Salovey and Mayer, consider it as «the ability to perceive, value and express emotions accurately; the ability to access and generate feelings that facilitate thinking; the ability to understand emotion and emotional knowledge; and the ability to regulate emotions and promote emotional and intellectual growth « (Mayer \& Salovey, 1997). Since this approach EI refers to a set of skills that allow people to solve problems adaptively by promoting emotional growth. EI according to Goleman (1995), is the ability of the human being to control and regulate the feelings of oneself, of others and to use emotion and feeling as a guiding element of thoughts and actions.

The literature indicates that effective youth development programmes can have an impact on social, emotional and physical health related to the transfer of positive behaviours, attitudes and life skills (Catalano et al., 2004; Durlak et al., 2011). Within the Positive Youth Development paradigm, there is a special attention on sport and physical activity programming (Coakley, 2011; Wright et al., 2016). Following this approach, the Teaching Personal and Social Responsibility model (TPSR) (Hellison, 2011) highlighted the need to teach, through physical education (PE) and sports, values, life skills, and socio-emotional competences that can provide the positive development of students' daily life. Within these life skills we find empathy and the management of emotions (WHO, 1999).

The cornerstone of the TPSR model is that the students, in order to be socially adapted, have to be responsible for themselves and with others in physical activity settings, and to learn strategies to exercise control over their life (Richards \& Gordon, 2017). The model interprets responsibility as a moral position with respect to oneself and others. In this sense, the values related to personal responsibility are effort and autonomy. The values related to social responsibility are respect for the feelings and rights of others, empathy, and social sensibility (Wright, et al., 2016). The basic premise of the TPSR model is that responsible behaviour and life skills can be taught to pupils through the goals or levels that they gradually achieve, and these skills can be transfered 'outside of the gym' (Escartí et al., 2018).

Several years of field work and research (Escartí et al., 2005), support the feasibility and relevance of TPSR in the Spanish context. Pascual et al. (2011) itemized the key teaching processes designed into the TPSR model as follows: (1) create a psychologically and emotionally safe learning environment, (2) establish a positive relationship with participants based on respect, empathy and caring, (3) foster individual potential and build on participants' strengths, (4) facilitate empowerment and autonomy, (5) help participants gain confidence to accept challenges and set goals, (6) act with coherence and sincerity (role model), and (7) demonstrate mastery of physical activity content and the ability to integrate this with experiences that foster personal and social responsibility.

The TPSR-based programmes have been implemented in different grades from primary and secondary education, in different contexts (i.e. most studies had at-risk students), during PE classes as part of the academic curriculum, or in out-of-school sport and extended day programmes (Richards \& Gordon, 2017). Some authors (Martinek \& Hellison, 2016; SánchezAlcaraz et al., 2020; Wright, et al., 2016) consider the TPSR model to be an ideal framework for designing PE classes and the rest of the school curriculum. Others highlight its utility as a method for teaching values to special groups, in particular children and young people at risk (Wright, et al., 2016). Thus, most studies using TPSR-based programmes have been aimed at students from low socioeconomic status neighbourhoods (Escartí, et al., 2018; Wright \& Irwin, 2018). Although there is some research with positive outcomes in middle-class neighbourhoods, there are no examples of studies that compare the same intervention programme in two socioeconomic areas. Such a distinction is needed because the mechanisms underlying social and emotional skill development through sports may differ for these two youth groups (Haudenhuyse et al., 2014).

Most investigations in the TPSR literature have used qualitative approaches, while quasi-experimental designs are scarce (Gordon, 2010; Wright et al., 2010). Pozo et al. (2018) analysed TPSR-based programmes within PE in their systematic review. After reviewing 22 studies 
that met the standards of methodological rigor to be disseminated through peer-reviewed publication, the authors concluded by affirming the necessity of conducting longer studies with follow-up data, quantitative methodological designs (as they might provide objective and controlled measurement and their findings can possibly be generalized) and larger samples. These authors presented evidence that students improved social and emotional competences as self-control, caring, relatedness, conflict resolution, self-esteem and empathy (DeBusk \& Hellison, 1989; Cecchini et al, 2003, 2007). Due to these promising findings, they suggested that future investigations should be focused on the transfer of values and social skills to academic performance and students' daily life, especially with disadvantaged populations and at-risk children and adolescents. However, few of these studies have analyzed the influence of TPSR-based programmes on EI.

Focusing on the improvements in empathy of $\mathrm{PE}$ students after the application of a Cooperative Learning programme, Goudas and Magotsiou (2009) and Yoder (1993) found positive effects of that programme. In the same way, various authors (Fernandez-Rio \& MenéndezSanturio, 2017; Hastie \& Sinelnikov, 2006; Menéndez \& Fernandez-Rio, 2017; Wallhead \& Ntoumanis, 2004) found an increase in empathy after applying programmes of Sport Education in PE. However, studies by GarcíaLópez et al. (2015; 2012) showed decreases in student empathy after a season of SE. Within the field of TPSRbased programmes, previous studies (Buckle \& Walsh, 2013; Caballero, 2012; Cecchini et al., 2007) showed a positive effect on students' empathy. Likewise, Gutiérrez et al. (2011) reported that empathy was a predictor of personal and social responsibility.

With regard to EI, in recent years, many studies positively link PE classes and the development of students' EI (Alonso et al., 2020). Rivera-Pérez et al. (2020) found positive associations between CL and EI in PE. Some of EI dimensions are included in social and emotional learning (SEL). With this in mind, numerous studies highlighted the positive effects of TPSR-based programmes on SEL (Belando et al., 2012; Dyson et al., 2020; Gordon, 2016).

Nevertheless, it is clear from Dyson et al.'s review that research into TPSR has aligned findings with SEL outcomes that demand further explicit and empirical evidence for their further legitimization. In this study, we are especially interested in the influence of the TPSR model on social responsibility, since our purpose is to measure the effects on empathy and EI. We consider these variables as fundamental in conflict resolution and social interaction that takes place in PE classes. Empathy is fully related to programme level I ('respecting the rights and feelings of others') and IV ('caring'). However, the TPSR programme does not specifically address the training of emotional competencies, although its inclusion seems interesting to us in order to find a relationship between the different values proposed by the programme and EI.

Therefore, this study's aims were: (1) to analyse the effects of a teaching programme within PE on empathy and perceived EI; and (2) to compare the scores between lower-middle and upper-middle socioeconomic context schools.

\section{Methodology}

\section{Participants and settings}

Participants were 210 (110 girls and 100 boys) students from 4 primary schools of southern Spain. Students' age ranged from 10 to 12 years $(M=11.04$; $S D=.497)$, they studied in the sixth grade of elementary school, and they had no prior experience with the programme. The socioeconomic context of each school was different; 2 schools were located in uppermiddle class neighbourhoods, whereas the other 2 schools were located in lower-middle class neighbourhoods (classified by the Andalusian government as 'lowperforming schools' and troubled with marginalization and delinquency). To determine the sociocultural level of the students, the level of studies, income and occupation of the neighborhood have been taken into account.

A total of 8 class sections were involved in the 4 schools, with a mean of 26.25 students per class. There were 2 intact class sections at each of the 4 schools; 1 was randomly assigned to the intervention group $(n=103,55$ from the upper-middle context, 48 males) and the other to the comparison group $(n=107,57$ from the upper-middle context, 52 males).

4 voluntary PE teachers from each school participated in the study. Each of them had a comparison group and an intervention group. At the time of the implementation, the teacher from school A was 34 years old and male. He held a degree in PE with 6 years of teaching experience. The teacher at school B was 40 years old and female. She held a degree in PE and 10 years of teaching experience. The teacher at school $\mathrm{C}$ was 33 years old and male. He held a degree in physical 
activity and sports science with 7 years of teaching experience. Finally, the teacher at school D was 44 years old and male. He held a degree in physical activity and sport science with 10 years of experience. None had previous experience in implementing the TPSR programme.

\section{Procedure}

Programme description. The structure and strategies of the model were applied to help students learn and practice behaviours and attitudes that will help them become responsible individuals. These responsibilities were presented as a progression of five levels. Teachers were instructed to operationalize these levels in relevant learning objectives and behaviours to help students develop a concrete understanding of each (Escartí, et al., 2018). Level I was 'respecting the rights and feelings of others' (e.g., peaceful conflict resolution, including all peers in the activities, listening to the teacher and classmates when they are speaking, speaking without interrupting others) and level II was 'participation and effort' (e.g., giving good effort, participating in planned activities even when they are not your favourite, persisting in all activities even when they are difficult, following the rules and procedures of the class). Level III focused on 'self-direction' (e.g., setting short- and long-term goals, reflecting on and evaluating your own progress honestly, assuming responsibility for tasks, participating in activities whether the teacher is watching or not). Level IV was on 'caring' (e.g., helping others, paying attention to the needs of your classmates, taking on leadership roles), and level V concentrated on 'transfer' (e.g., thinking about and applying the learning from previous levels to other contexts such as the family, the playground, or the neighbourhood).

Teachers were encouraged to use a consistent daily structure for implementing the programme. Each class in the intervention programme followed a format that used the typical structure of the TPSR model. Thus, the session outline was divided into 4 parts: (1) 'awareness talk': it was a group meeting with a brief reminder of the levels of responsibility and goals of the day; (2) 'responsibility in action': in this part the PE contents were taught, at the same time as the principles and methodological strategies for the development of responsibility were applied; (3) 'reflection time': it allowed time for all participants to share their perceptions and feelings about the lesson development and how to improve the programme; and (4) 'selfassessment': students evaluated themselves on how they had fulfilled the level of responsibility, and they justified it with reasons.

A range of pedagogical strategies suggested by Wright and Craig (2011) to show high quality, responsibility-based instruction were employed by the teachers of the intervention: (1) modelling respectful behaviour (the teacher communicates respectfully by being a model); (2) setting clear expectations (the teacher explains or refers to explicit behavioural expectations); (3) fostering social interaction (the students could work not only as partners but also to engage in formal self- and peer-assessment); (4) providing opportunities for success (the teacher structures the lesson so that all students can participate and experience success); (5) assigning management tasks

\begin{tabular}{|c|c|c|c|c|}
\hline $\begin{array}{l}\text { Level } \\
\end{array}$ & Objectives & Pedagogical strategies & Teaching units & Teacher attitudes \\
\hline $\begin{array}{l}\text { Level I. } \\
\text { Respect others and create a good } \\
\text { environment } \\
\text { (October-November) }\end{array}$ & $\begin{array}{l}\text { - Know and respect the rules of coexistence } \\
\text { - Listen to the teacher and classmates respecting everyone's turn to speak } \\
\text { - Solve conflicts in a negotiated and autonomous way } \\
\text { - Self-control and never use violence (beat, insult ...) } \\
\text { - Accept all classmates without discrimination }\end{array}$ & $\begin{array}{l}\text { Agreed elaboration of the class rules } \\
\text { Change the rules } \\
\text { Make teams } \\
\text { Peace bench } \\
\text { Time out } \\
\text { Individual and group contracts }\end{array}$ & $\begin{array}{l}\text { Physical condition (6 sessions) } \\
\text { Judo ( } 6 \text { sessions) } \\
\text { Body expression ( } 4 \text { sessions) }\end{array}$ & \multirow{5}{*}{$\begin{array}{l}\text { 1. Create a safe and } \\
\text { trusted environment } \\
\text { 2. Respect, help and } \\
\text { care about children } \\
\text { 3. Focus on the } \\
\text { individual strengths } \\
\text { 4. Empower } \\
\text { progressively children } \\
\text { 5. Empathize } \\
\text { 6. Have high } \\
\text { expectations for } \\
\text { students } \\
\text { 7. Be coherent and } \\
\text { honest } \\
\text { 8. Master the subject } \\
\text { 9. Teach personal and } \\
\text { social responsibility }\end{array}$} \\
\hline $\begin{array}{l}\text { Level II. } \\
\text { Participation } \\
\text { and effort } \\
\text { (December-January) }\end{array}$ & $\begin{array}{l}\text { - Intrinsic motivation } \\
\text { - Participate in all } \\
\text { activities even if they do not like, they do not feel like it or they are not } \\
\text { good at. } \\
\text { - Strive, do not abandon and pay attention to tasks. } \\
\text { - Demonstrate interest and motivation in the activities } \\
\end{array}$ & $\begin{array}{l}\text { Task diversification } \\
\text { Redefine success } \\
\text { Intensity scale }\end{array}$ & Athletics (12 sessions) & \\
\hline $\begin{array}{l}\text { Level III. } \\
\text { Personal autonomy } \\
\text { (February) }\end{array}$ & $\begin{array}{l}\text {-Improve the perception of the ability and self-confidence } \\
\text { - Carry out activities independently } \\
\text { - Set short and long term goals } \\
\text { - Self-evaluate consistently } \\
\text { - Assume leadership roles }\end{array}$ & $\begin{array}{l}\text { Goal setting } \\
\text { Personal work plan } \\
\text { Performance of leadership roles and } \\
\text { decision making }\end{array}$ & $\begin{array}{l}\text { Football ( } 4 \text { sessions) } \\
\text { Volleyball ( } 4 \text { sessions) }\end{array}$ & \\
\hline $\begin{array}{l}\text { Level IV. } \\
\text { Help and leadership } \\
\text { (March) }\end{array}$ & $\begin{array}{l}\text { - Help others when they need and ask for help } \\
\text {-Repair and listen to others } \\
\text { - Act without expecting any reward } \\
\text { - Identify and express one's own emotions and recognize the emotions of } \\
\text { others } \\
\text { - Know what assertiveness is in order to improve communication } \\
\text { - Know the importance of cooperating to achieve a common goal }\end{array}$ & $\begin{array}{l}\text { Chain of favours } \\
\text { Group goals } \\
\text { Reciprocal training }\end{array}$ & $\begin{array}{l}\text { Acrosport ( } 4 \text { sessions) } \\
\text { Badminton and tennis ( } 4 \\
\text { sessions) }\end{array}$ & \\
\hline $\begin{array}{l}\text { LevelV. } \\
\text { Transference } \\
\text { (April-May) }\end{array}$ & $\begin{array}{l}\text { - Put into practice what was learned in other areas of life (school, family, } \\
\text { neighborhood ...) } \\
\text { - Be a model for others }\end{array}$ & Give responsibilities & $\begin{array}{l}\text { Alternative games (12 } \\
\text { sessions) }\end{array}$ & \\
\hline
\end{tabular}


(the teacher assigns specific tasks and responsibilities to the students); (6) promoting leadership (the teacher empowers students to be in charge of a group); (7) giving choices and voices (the teacher gives students a voice and promotes them to make decisions); and (8) addressing the transfer of life skills (the teachers reflect with their students on the possibility of transferring what has been learned to other contexts). These strategies are not exhaustive but represent active learning and empowerment-based tools that are seen less often in practice (Wright \& Irwin, 2018).

Finally, Marín (2011) delimited the key components of TPSR in: (1) responsibility levels, (2) specific objectives of each level, (3) strategies that teachers should use to teach responsibility levels, (4) teaching units elaborated as PE content, and (5) the teachers' attitudes. These key components and the timing have been used to define the procedure of the TPSR-based programme implementation, and they have been detailed in Table 1.

Training for teachers. A doctor in physical activity and sports sciences, with experience in studying and developing the TPSR model, led the teacher training course. The $4 \mathrm{PE}$ teachers responsible for carrying out the intervention received an intensive course of 30 hours (Escartí et al., 2005; Hellison, 2011) during the first week of September. This training course had an active and participatory methodology with practical classes. Its contents included: a) theoretical foundation about the principles and methodologies of the TPSR model; and $b$ ) practical classes where the specific strategies of each level were applied. During the intervention period, continuous contact through 2 -hr weekly meetings with the teachers was maintained with the objective of facilitating the teaching tasks as they conducted the training programme's strategies and the PE contents.

Programme implementation. The TPSR-based programme was implemented over 8 months (56 lessons) during the two weekly classes of PE in the intervention group. The duration of the lessons was 55 minutes. The teachers implemented the TPSR model in the intervention group integrating the programme with the PE teaching units and applying the pedagogical strategies in each level suggested in Table 1. All 4 primary schools adopted the same PE contents described in Table 1 (teaching units). The $4 \mathrm{PE}$ teachers were responsible for carrying out the implementation in both the intervention and comparison groups. The TPSR original model was adapted to our context following Escartí et al. work (2005). It was decided that shaping the programme to fit the specific context could enhance implementation without deviating from the key TPSR components. For instance, as a design measure to add structure and simplicity, we decided to introduce the responsibility levels progressively as a series of goals. Moving from level I up to level V over the course of the academic year but being able to reuse previous strategies at certain times, when the teacher deems it convenient. The overcoming of the different levels by a majority of students was verified through a rubric where the observable behaviors of each level were evaluated. We also selected specific objectives to emphasize under each level (see Table 1).

\section{Instruments}

Empathy. A Spanish version of the Bryant's Empathy Index for children and adolescents (Bryant, 1982; Del Barrio et al., 2004) was used to measure empathy. This questionnaire contains 22 items, distributed in 3 factors: feelings of sadness, understanding feelings, and tearful reaction with regard to the emotions of others. Example items included: 'girls who cry because they are happy are silly', and 'some songs make me so sad I feel like crying'. The instrument used had a 3-point scale of agreement versus disagreement $(1=$ 'very strong disagreement' to 3 = 'very strong agreement'). The analysis of internal consistency indicated Cronbach's alpha of .73.

Emotional intelligence. The Trait Meta-Mood Scale (Salovey et al., 1995; Spanish version by Fernández-Berrocal et al., 2004) is a measure of perceived EI in terms of individuals' beliefs about their own EI. It is a five-point Likert scale (1 corresponded to 'strongly disagree', and 5 corresponded to 'strongly agree') with 24 items grouped in 3 subscales: (1) emotional attention: conveys to what extent individuals tend to observe and think about their feelings and moods; (2) emotional clarity: evaluates the understanding of one's emotional states; and (3) emotional repair: refers to the individuals' beliefs about ability to regulate their feelings. Example items included: 'I pay a lot of attention to how I feel', 'I am usually very clear about my feelings', and 'when I become upset, I remind myself of all the pleasures in life'. The analysis of internal consistency indicated Cronbach's alpha of .71.

\section{Data collection}

The study received the approval of the university committee. Active parental consent was obtained from 
all research participants prior to conducting the fieldwork.

Students completed the pre and post-tests related to empathy and perceived EI at the beginning (September) and end (June) of the programme. The 2 questionnaires were given individually to each of the participants (both intervention and comparison groups) in the classroom by each PE teacher. 14 questionnaires were invalid because the students did not complete 1 of the 2 measures.

\section{Research design}

The quasi-experimental repeated measures design of the present study included quantitative analysis of data from the intervention and the comparison groups in four schools. The design of the study took into account the Spanish legal framework that regulates the protection of personal data according to Organic Law 15/1999, and the fundamental principles established by the Helsinki Declaration (reviewed in 2013, Brazil).

\section{Data analysis}

The data analysis was conducted with the statistical programme SPSS 21.0 (Chicago, IL), and was divided into two parts: a preliminary analysis, and an analysis of the intervention effects.

First, the descriptive statistics of each variable in pre-test and post-test were calculated according to the groups to which the students belonged. Then, the repeated measures method of the general linear model was used for differences in dependent variables (empathy and EI). There were no differences between groups at baseline for the study variables.

2 analyses of covariance (ANCOVA) were completed: The first was a two (Group) $\times$ two (Time) ANCOVA to analyse empathy and EI results in each group (intervention/comparison) in pre- and postintervention. The second was a two (Context) $\times$ two (Time) measure to study empathy and EI differences by school socioeconomic context (upper-middle/lowermiddle) in the intervention groups. The main interest was the interaction effect because it shows the effects of the intervention over time. For all the analyses, a 95\% confidence level was used $(p<.05)$. The relative percentage change between pre- and post-measures was calculated as follows: [(post measure - pre measure)/ pre measure] $\times 100$. Eta-squares were calculated to assess effect-size, defining small $\left({ }^{2}=.01\right)$, medium $\left(\mathrm{h}^{2}\right.$ $=.06)$, and large $\left(\mathrm{h}^{2}=.14\right)$ effects. The analyses were adjusted by gender and age.

\section{Results}

This section presents the results of the ANCOVA on empathy and EI of students. As each school had two natural groups, this meant the realization of a design with non-equivalent groups. The comparison and intervention group allocation was randomized.

\section{Empathy and Emotional intelligence}

To measure empathy, we used the Spanish version of the Bryant's Empathy Index for children and adolescents (Bryant, 1982; Del Barrio et al., 2004). This questionnaire was distributed in three factors: feelings of sadness, understanding feelings, and tearful reaction with regard to the emotions of others.

Regarding perceived EI, we used the Trait MetaMood Scale (Salovey et al., 1995; Spanish version by Fernández-Berrocal et al., 2004). It is divided into three subscales: emotional attention, emotional clarity, and emotional repair.

Table 2, which shows the comparative relation between intervention and comparison groups, presented a positive interaction effect on feelings of sadness $(p<$ $\left..05 ; ?^{2}=.020\right)$, although the effect size was small. Regarding the EI variable, no significant results were found.

\begin{tabular}{l} 
Table 2 \\
$\begin{array}{l}\text { Descriptive analysis and results of ANCOVA two (group) } \\
\text { factors. }\end{array}$ two (time) of empathy and emotional intelligence \\
\hline Variables and subscales
\end{tabular}

Table 3, which reflects the socioeconomic contexts comparison, presents a greater effect on feelings of sadness $\left(p=.016 ; \mathrm{h}^{2}=.054\right)$ in the lower-middle context group compared to the upper-middle. The intervention was more effective on understanding feelings $\left(p<.001 ; \mathrm{h}^{2}=.116\right)$ in the upper-middle context group. Likewise, the intervention was more effective in improving the total EI score $\left(p=.017 ; \mathrm{h}^{2}=.054\right)$, attention $\left(p<.05 ; \mathrm{h}^{2}=.038\right)$ and repair $\left(p<.026 ; \mathrm{h}^{2}=\right.$ $.047)$ in the lower-middle context group compared to the upper-middle context group. 
Descriptive analysis and results of ANCOVA two (socioeconomic context) $\times$ two (time) of empathy and emotional intelligence factors.

\begin{tabular}{|c|c|c|c|c|c|c|}
\hline \multirow{2}{*}{ Variables and subscales } & \multirow{2}{*}{ Context } & \multirow{2}{*}{$\begin{array}{c}\text { Pre } \\
\mathrm{M}(\mathrm{SD})\end{array}$} & \multirow{2}{*}{$\begin{array}{c}\text { Post } \\
\mathrm{M}(\mathrm{SD})\end{array}$} & \multicolumn{3}{|c|}{ Context $\times$ Time } \\
\hline & & & & $p$ & $\eta^{2}$ & $1-\beta$ \\
\hline \multirow{2}{*}{ Empathy total score } & Lower-1 & $2.173(0.231)$ & $2.228(0.350)$ & \multirow[b]{2}{*}{.2} & \multirow{2}{*}{.010 } & \multirow{2}{*}{.164} \\
\hline & & $2.195(0.222)$ & $2.256(0.237)$ & & & \\
\hline \multirow{2}{*}{ Feelings of sadness } & Lower & $2.302(0.414)$ & $2.638(0.292)$ & \multirow{2}{*}{.016 } & \multirow{2}{*}{.054 } & \multirow{2}{*}{.683} \\
\hline & Upper & $2.370(0.420)$ & $2.498(0.412)$ & & & \\
\hline \multirow{2}{*}{ Understanding feelings } & Lower- & $1.749(0.439)$ & $1.488(0.265)$ & \multirow{2}{*}{$<.001$} & \multirow{2}{*}{.116} & \multirow{2}{*}{9} \\
\hline & Upper-middle & $1.535(0.286)$ & $1.544(0.264)$ & & & \\
\hline \multirow{2}{*}{ Tearful reaction } & Lo & 1.889 & 1.918( & \multirow{2}{*}{.354} & \multirow{2}{*}{.008} & \multirow{2}{*}{.152} \\
\hline & $\mathrm{u}_{\mathrm{p}}$ & $1.582(\mathrm{C}$ & 1.917( & & & \\
\hline \multirow{2}{*}{$\begin{array}{l}\text { Emotional intelligence } \\
\text { total score }\end{array}$} & Lower-middle & $3.472(0.697)$ & $3.655(0.649)$ & \multirow{2}{*}{.017} & \multirow{2}{*}{.054} & \multirow{2}{*}{.674 } \\
\hline & Upper-middle & $3.387(0.593)$ & $3.151(0.740)$ & & & \\
\hline \multirow{2}{*}{ Attentic } & Lower-n & $3.254(0.867)$ & $3.426(0.599)$ & \multirow{2}{*}{.044 } & \multirow{2}{*}{.038} & \multirow{2}{*}{.525} \\
\hline & & $3.055(0.784)$ & $2.788(0$ & & & \\
\hline \multirow{2}{*}{ Clarity } & Lo & $3.463(0.797)$ & $3.506(0.897)$ & \multirow{2}{*}{.091} & \multirow{2}{*}{.027 } & \multirow{2}{*}{393} \\
\hline & & $3.435(0.731)$ & $3.117(0.887)$ & & & \\
\hline \multirow[b]{2}{*}{ Repair } & Low & $3.699(0.829)$ & $4.033(0.638)$ & \multirow[b]{2}{*}{.026} & \multirow{2}{*}{.047} & \multirow[b]{2}{*}{.608 } \\
\hline & Upper-n & $3.665(0.802)$ & $3.559(0.961)$ & & & \\
\hline
\end{tabular}

\section{Discussion}

The current paper examined a TPSR-based programme intervention in primary school PE classes in order to measure its effects on the students' empathy and perceived EI.Thus, a quasi-experimental design was used to determine the significance of the changes after the intervention, and to compare the results between lower-middle and upper-middle socioeconomic context schools.

First, the programme implementation has been shown to increase feelings of sadness. Several authors (Vincent, 2003; Thorlakson, 2004) concluded that educational programmes can increase empathy levels of children. These conclusions reinforce findings from previous studies in the TPSR model's field (Buckle \& Walsh, 2013; Caballero, 2012; Cecchini et al., 2007). Likewise, a relationship can be established with the study by Gutiérrez et al. (2011), which showed that empathy was a predictor of personal and social responsibility. The dynamics and operation of the TPSR-based programme proposes in levels I and IV activities that will allow to develop empathy with others and a sense of belonging, so it was expected to be able to find an improvement in empathy.

In addition, positive effect on empathy in other SELbased programmes has been showed as in Cooperative Learning (Goudas \& Magotsiou, 2009; Yoder, 1993) and Sport Education (Fernandez-Rio \& Menéndez-Santurio, 2017; Hastie \& Sinelnikov, 2006; Menéndez \& Fernandez-Rio, 2017; Wallhead \& Ntoumanis, 2004). Nonetheless, Bessa et al. (2019) mentioned that the different interests and motivations among students that occur throughout the SE season can lead some students to adopt more egocentric positions, and not to put themselves in the place of the other. This was highlighted in the studies of García-López et al. $(2015$; 2012) where they reported that empathy has decreased maybe due to large number of situations that occur within a SE season in which there is a clash of interests between students.

On the contrary, no significant results have been found in EI.These results can be interpreted in the sense that the TPSR programme implementation does not offer specific pedagogical strategies and programme levels to train emotional competencies. Several studies (Bruno et al., 2002; Grinspan et al., 2003; Siskos at al., 2011) argued that children's abilities in recognizing, understanding and managing emotions may be supported by a specific designed programmes and teaching methods. For example, Rivera-Pérez et al. (2020) found positive and significant associations between CL and EI. Although it is not the same construct, many aspects of EI and SEL coincide. Thus, numerous studies point to the positive effects of TPSR-based programmes on SEL (Belando et al., 2012; Dyson et al., 2020; Gordon, 2016).

Second, we find that the effects on understanding feelings were greater in the upper-middle socioeconomic context group, while the effects on EI, attention, and repair were greater in the lower-middle context group. However, it is important to point out that the significant change difference in these sub-scales most probably cause the significant change difference in EI (total score). This results are not surprising since the TPSR programme design is specifically aimed at underserved populations, and it is more adapted to the improvement of empathy and EI that are usually necessary in PE classes. Research has focused on the acquisition of emotional competencies in various socioeconomic contexts with different results. In North America, BarOn (1997) concluded that there were no significant differences in socio-emotional intelligence between various ethnic groups from different socioeconomic contexts.

On the contrary, findings indicated that a better socioeconomic level turns out to be a more favourable starting point for well-being, self-esteem, vital satisfaction, and psychological adjustment (Twenge \& Nolen-Hoeksema, 2002; Pertegal, 2014). Furthermore, the family socioeconomic level was a positive predictor of the emotional understanding and regulation (Pertegal, 2014; Pertegal \& Oliva; 2017). In both studies it is considered that behind the possible influence of the socioeconomic level in perceived EI, it would be necessary to study and isolate whether that variable is covering different practices related to emotional education that occur at home, which were really the 
causes of such differences, e.g., understanding and emotional regulation of adolescents.

Some limitations to the study should be noted. We must clarify that the TMMS-24 scale is a self-report test that evaluates the perception, assessment and awareness of emotional capacities, not the emotional competence itself. It would be important to apply observations of the behaviours in the educational context, in order to check the degree of coincidence between the manifestations of students and their actual performances. Further, the questionnaires applied did not encompass the real situations arising during the programme in a PE class. It also might be interesting to consider the differences presented by groups of different ages in the studied variables, or carry out a mixed study in which qualitative information can be triangulated on the perception of students and teachers on the variables under study.

On the other hand, among the strengths we can highlight that the current work covers a field of limited interventions in Europe, and it is important to mention that the duration of the study and the sample used was higher than the average in this type of studies (Pozo et al., 2018).

It would be important that future studies examine in depth the complex relationship between the physical, emotional, cognitive, and social aspects in PE, and it is important the need for coordinating efforts across academic areas to allow students to practice and apply social and emotional competencies in different learning contexts. Furthermore, the relationship between socio-cultural differences and emotional well-being is a field for future research.

Although the contribution from PE is quite important, in order to achieve a greater reach, we need global positive youth development programmes that involve different services (health, education, youth, social services) and to be developed locally (Parra et al., 2009; Pertegal et al., 2010; Lu \& Buchanan, 2014). EI and empathy are particularly important for children, as they can help to understand their mood, improve their social relationships and enhance conflict resolution.

In conclusion, it has been proven the effectiveness of aTPSR-based programme to foster social and emotional competencies, and it seems to work better with children from disadvantaged contexts. PE is an ideal setting in which students can develop social and emotional skills that can be applied to other life contexts. Physical educators should be aware of students' developmental needs and the practices for developing their emotional growth. An emphasis on respect, cooperation and conflict resolution, are fundamentals for teaching these important life skills.

\section{References}

Alonso, D., León-Del-Barco, B., Mendo-Lázaro, S., \& Gallego, D. (2020). Examining Body Satisfaction and Emotional-Social Intelligence among School Children: Educational Implications. International Journal of Environmental Research in Public Health, 17(6), 2120. doi:10.3390/ijerph17062120

Bar-On, R. (1997). The Emotional Quotient Inventory (EQi): Technical manual. Toronto, Canada: Multi-Health Systems, Inc.

Belando, N., Férriz-Morell, R., \& Moreno Murcia, J. A. (2012). Mejora personal y social a través de la promoción de la responsabilidad en la actividad físicodeportiva (Personal and social improvement through the promotion of responsibility for physical and sporting activity). RICYDE. Revista Internacional de Ciencias del Deporte, 8(29), 202-222. doi: 10.5232/ ricyde2012.02902

Bessa, C., Hastie, P., Araújo, R., \& Mesquita, I. (2019). What do we know about the development of personal and social skills within the sport education model: A systematic review. Journal of Sports Science \& Medicine, 18(4), 812-829.

Bosacki, S. (2008). Children's emotional lives: Sensitive shadows in the classroom. New York, NY: Peter Lang.

Bruno, K., England, E., \& Chambliss, C. (2002). Social and emotional learning program for elementary school students: A pilot study. Ursinus College, Collegeville, Pennsylvania. Retrieved from https:/ / eric.ed.gov/?id=ED463097

Bryant, B. (1982). An index of empathy for children and adolescents. Child Development, 53 (2), 413-425. Doi:10.2307/1128984

Buckle M. E., \& Walsh, D. S. (2013). Teaching responsibility to gang-affiliated youths. Journal of Physical Education, Recreation \& Dance, 84 (2), 53-58. Doi: 10.1080/07303084.2013.757193

Bywater, T., \& Sharples, J. (2012). Effective evidencebased interventions for emotional well-being lessons for policy and practice. Research Papers in Education, 27 (4), 389-408. doi: 10.1080/ 02671522.2012 .690242

Caballero, P. J. (2012). Diseño y evaluación de un programa de responsabilidad personal y social a través de actividad física en el medio natural en estudian- 
tes de formación profesional [Design and evaluation of a program of personal and social responsibility through physical activity in the natural environment in vocational students] (Unpublished doctoral dissertation). Pablo de Olavide University, Seville, España.

Catalano, R. F., Berglund, M. L., Ryan, J. A., Lonczak, H. S., \& Hawkins, D. (2004). Positi-ve youth development in the United States: Research findings on evaluations of positive youth development programs. The Annals of the American Academy of Political and So-cial Science, 591 (1), 98-124. Doi: 10.1177/ 0002716203260102

Cecchini, J. A., Montero, J., Alonso, A., Izquierdo, M., \& Contreras, O. (2007). Effects of personal and social responsibility on fair play in sports and self-control in school-aged youths. European Journal of Sport Science, 7(4), 203-211. doi:10.1080/ 17461390701718497

Cecchini J.A., Montero J., \& Peña, J.V. (2003). Repercusiones del programa de intervención para desarrollar la responsabilidad personal y social de Hellison sobre los comportamientos de fair-play y el auto-control. Psicothema, 15(4), 631-637.

Coakley, J. (2011).Youth sports: What counts as 'positive development?' Journal of Sport \& Social Issues, 35(3), 306-324. doi:10.1177/0193723511417311

DeBusk, M. \& Hellison, D. (1989). Implementing a physical education self-responsibility model for delinquency prone youth. Journal of Teaching in Physical Education 8(2), 104-112.

Del Barrio, V., Aluja, A., \& García, L. F. (2004). Bryant's empathy index for children and adolescents: Psychometric properties in the Spanish language. Psychological Reports, 95 (1), 257-262. doi: 10.2466/ pr0.95.1.257-262

Durlak, J. A., Weissberg, R. P., Dymnicki, A. B., Taylor, R. D., \& Schellinger, K. B. (2011). The impact of enhancing students' social and emotional learning: A meta-analysis of school-based universal interventions. Child Development, 82(1), 405-432. doi:10.1111/j.1467-8624.2010.01564.x

Dyson, B., Howley, D., \&Wright, P. M. (2020).A scoping review critically examining research connecting social and emotional learning with three modelbased practices in physical education: Have we been doing this all along? European Physical Education Review, 27(1), 76-95. doi:10.1177/1356336X20923710

Eisenberg, N., Eggum, N. D., \& Di Giunta, L. (2010). Empathy-related responding: associations with prosocial behavior, aggression, and intergroup relations. Social Issues and Policy Review, 4(1), 143180. doi:10.1111/j.1751-2409.2010.01020.x

Escartí, A., Llopis-Goig, R., \& Wright, P. M. (2018). Assessing the implementation fidelity of a schoolbased teaching personal and social responsibility program in physical education and other subject areas. Journal of Teaching in Physical Education, 37(1), 12-23. doi:10.1123/jtpe.2016-0200

Escartí, A., Pascual, C., \& Gutiérrez, M. (2005). Responsabilidad personal y social a través de la educación fisica y el deporte [Personal and social responsibility through physical education and sport]. Barcelona: Graó.

Fernández-Berrocal, P., Extremera, N., \& Ramos, N. (2004). Validity and reliability of the Spanish modified version of the Trait Meta-Mood Scale. Psychological Reports, 94, 751-755. doi:10.2466/ pr0.94.3.751-755

Fernandez-Rio, J. \& Menéndez-Santurio, J. (2017) Teachers and students' perceptions of a hybrid sport education and teaching for personal and social responsibility learning unit. Journal of Teaching in Physical Education, 36 (2), 185-196. doi:10.1123/ jtpe.2016-0077

Garaigordobil, M. \& García de Galdeano, P. (2006) Empathy in children aged 10 to 12 years. Psicothema, 18(2), 180-186.

García-López, L.M., \& Gutiérrez, D. (2015).The effects of a sport education season on empathy and assertiveness. Physical Education and Sport Pedagogy, 20 (1); 1-16. doi:10.1080/17408989.2013.780592

García-López, L. M., Gutiérrez, D., González-Villora, S., \& Valero-Valenzuela, A. (2012). Cambios en la empatia, la asertividad y las relaciones sociales por la aplicacion del modelo de instruction education deportiva [Changes in empathy, assertiveness and social relations through the application of the model of sports education education]. Revista de Psicología del Deporte, 21 (2): 321-330.

Goleman, D. (1998) Working with Emotional Intelligence; Bantam: New York, NY, USA.

Gómez-Sánchez,V., Padial-Ruz, R., Gentil-Adarve, M., \& Chacón-Zagalaz, J. (2019). Implicaciones del Deporte Federado hacia la Empatía y Actitud a la Educación Física en Adolescentes (Implications of Federated Sports towards Empathy and Attitude to Physical Education in Adolescents). Retos, 36, 412 417. doi: $10.47197 /$ retos.v36i36.71582

Gordon, B. (2010). An examination of the responsibility 
model in a New Zealand secondary school physical education program. Journal of Teaching in Physical Education, 29(1), 138-154. doi:10.1123/jtpe.29.1.21

Gordon, B., Jacobs, J. M., \& Wright, P. M. (2016). Social and Emotional Learning Through a Teaching Personal and Social Responsibility Based After-School Program for Disengaged Middle-School Boys. Journal of Teaching in Physical Education, 35(4), 358 369. doi: 10.1123/jtpe.2016-0106

Goudas, M., \& Magotsiou, E. (2009) The Effects of a cooperative physical education program on students' social skills. Journal of Applied Sport Psychology,21(3), 356-364. doi:10.1080/10413200903026058

Grinspan, D., Hemphill, A., \& Nowicki, J. S. (2003). Improving the ability of elementary school-age children to identify emotion in facial expression. The Journal of Genetic Psychology, 164 (1), 88-100. doi:10.1080/00221320309597505.

Gutiérrez, M., Escartí, A., \& Pascual, C. (2011). Relationships among empathy, prosocial behavior, aggressiveness, self-efficacy and pupils' personal and social responsibility. Psicothema, 23 (1), 13-19. Retrieved from http:/ /www.psicothema.com/ psicothema.asp?ID=3843.

Hastie, P. \& Casey, A. (2014). Fidelity in models-based practice research in sport pedagogy: A guide for future investigations. Journal of Teaching in Physical Education, 33, 422-431. doi: 10.1123/jtpe.2013-0141.

Hastie, P., \& Sinelnikov, O. (2006) Russian students' participation in and

perceptions of a season of Sport Education. European Physical Education Review, 12(2), 131-150. doi:10.1177/ 1356336 X06065166

Hellison, D. (2011). Teaching responsibility through physical Activity (3rd ed.). Champaign, IL: Human Kinetics.

Hellison, D., \& Walsh, D. (2002). Responsibility-based youth program evaluation: Investigating the inves-tigations. Quest, 54(4), 292-307. doi: 10.1080/ 17408980802401252

Haudenhuyse, R., Theeboom, M., Nols, Z., \& Coussée, F. (2014). Socially vulnerable young people in Flemish sports clubs: Investigating youth experiences. European Physical Education Review, 20(2), 179-198. doi:10.1177/1356336X13508686

Jacobs, F., Knoppers, A., \& Webb, L. (2012). Making sense of teaching social and moral skills in physical education. Physical Education \& Sport Pedagogy, 18, 114. doi:10.1080/17408989.2011.621118

Lu, C., \& Buchanan, A. (2014). Developing student emotional well-being in physical education. Journal of Physical Education, Recreation and Dance, 85(4), 2833. doi:10.1080/07303084.2014.884433

Marín, D. (2011). Adaptación e implementación de un programa de intervención en la escuela a través de la educación física: El programa de responsabilidad personal y social [Adaptation and implementation of an intervention program in schools through physical education: The program of personal and social responsibility] (Unpublished doctoral dissertation). University of Valencia, Spain.

Macklem, G. L. (2011). Evidence-based school mental health services: Affect education, emotion regulation training, and cognitive behavioral therapy. New York, NY: Springer.

Martinek, T., \& Hellison D. (2016). Teaching personal and social responsibility: Past, present and future. Journal of Physical Education, Recreation \& Dance, 87(5), 9-13. doi:10.1080/07303084.2016.1157382

Mayer, J. D., \& Salovey, P. (1997). What is emotional intelligence? In P. Salovey \& D. J. Sluyter (Eds.), Emotional development and emotional intelligence: Educational implications (pp. 3-34). Basic Books: New York, NY, USA.

Menéndez, J. \& Fernandez-Rio, J. (2017) Hybridising Sport Education and Teaching for Personal and Social Responsibility to include students with disabilities. European Journal of Special Needs Education 32, 508-524. doi:10.1080/08856257.2016.1267943

Parra, A., Oliva, A., \& Antolín, L. (2009). Los programas extraescolares como recurso para fomentar el desarrollo positivo adolescente [Extracurricular programs as a resource to encourage positive teenage development]. Papeles del Psicólogo, 30 (3), 3-13.

Pascual, C., Escartí, A., Llopis, R., Gutiérrez, M., Marín, D., \& Wright, P. M. (2011) Implementation fidelity of a program designed to promote personal and social responsibility through physical education: A comparative case study. Research Quarterly for Exercise and Sport, 82, 499-511. doi:10.1080/ 02701367.2011 .10599783

Pertegal, M. A. (2014). Los centros de Educación Secundaria como promotores del desarrollo positivo adolescente [Secondary schools as promoters of positive youth development]. (Unpublished doctoral dissertation). University of Seville, Spain.

Pertegal, M.A. \& Oliva, A. (2017). A model on the contribution of school assets to the achievement of adolescents' well-being and academic performance. The Spanish Journal of Psychology, 20, 1-9. doi:10.1017/ sjp. 2017.47

Pertegal, M. A., Oliva, A., \& Hernando, A. (2010). Los 
programas escolares como promotores del desarrollo positivo adolescente [Promoting positive youth development through school-based programmes]. Cultura y Educación, 22 (1), 53-66. doi:10.1174/ 113564010790935169

Pozo, P., Grao-Cruces, A. \& Pérez-Ordás, R. (2018) Teaching personal and social responsibility modelbased programmes in physical education: A systematic review. European Physical Education Review 24, 56-75. doi:10.1177/1356336X16664749

Richards, K.A., \& Gordon, B. (2016). Socialisation and learning to teach using the teaching personal and social responsibility approach. Asia-Pacific Journal of Health, Sport, and Physical Education, 8(1), 19-38. doi:10.1080/18377122.2016.1272424

Rivera-Pérez, S., León-del Barco, B., Fernandez-Rio, J., González-Bernal, J., \& Iglesias-Gallego, D. (2020). Linking cooperative learning and emotional intelligence in physical education: Transition across school stages. International Journal of Environmental Research and Public Health, 17(14), 5090. doi:10.3390/ijerph17145090

Salovey, P., Mayer J., Goldman, S., Turvei, C., \& Palfai, T. (1995). Emotional attention, clarity, and repair: Exploring emotional intelligence using the Trait Meta-Mood Scale. In J.W. Pennebaker (Ed.), Emotion, Disclosure \& Health (pp. 125-154). Washington, D. C.: American Psychological Association.

Sánchez-Alcaraz, B., Ibáñez, J., Sánchez, C., Valero, A. \& Gómez, A. (2020). El modelo de responsabilidad personal y social a través del deporte: revisión bibliográfica. Retos, 37, 755-762. doi:10.47197/ retos.v37i37.67890

Siskos, B. N., Papaioannou, A. G., \& Proios, M. K. (2011). Causal effects between emotional intelligence and a perceived caring classroom climate in physical education. International Journal of Physical Education, 48 (1), 7-17.

Stormont, M. (2002). Externalizing behavior problems in young children: contributing factors and early intervention. Psychology in the School, 39, 127-138.

Thorlakson, C. L. (2004). Teaching and learning to care: An early years intervention program in emotional intelligence. (Unpublished doctoral dissertation). University of Manitoba, Canada.

Twenge, J. M., \& Nolen-Hoeksema, S. (2002). Age, gender, race, socioeconomic status, and birth cohort differences on the Children's Depression Inventory: A meta-analysis. Journal of Abnormal Psychology, 111 (4), 578-588. doi:10.1037/0021-843X.111.4.578
Vincent, D. S. (2003). The evaluation of the social-emotional intelligence program: Effects on fifth graders' prosocial and problem behaviors. (Unpublished doctoral dissertation). State University of New York.

Wallhead,T., \& Ntoumanis, N. (2004) Effects of a Sport Education Intervention on Students' Motivational Responses in Physical Education. Journal of Teaching in Physical Education, 23, 4-18.

World Health Organization (1999) Partners in life skills education. Geneva, Switzerland: World Health Organization, Department of Mental Health. Retrieved from: https://www.who.int/ mental_health/media/en/30.pdf (accessed 5 November 2021).

Wright, P. M., \& Craig, M.W. (2011). Tool for assessing responsibility-based education (TARE): Instrument development, content validity, and inter-rater reliability. Measurement in Physical Education and Exercise Science, 15(3), 204-219. doi:10.1080/ 1091367X.2011.590084

Wright, P. M., \& Irwin, C. (2018). Using systematic observation to assess teacher effectiveness promoting personally and socially responsible behavior in physical education. Measurement in Physical Education and Exercise Science. Advance online publication. doi:10.1080/1091367X.2018.1429445

Wright, P. M., Jacobs, J., Ressler, J. D. , \& Jung, J. (2016). Teaching for transformative educational experience in a sport for development program. Sport, Education and Society, 21(4), 531-548. doi:10.1080/ 13573322.2016.1142433

Wright, P. M., Li, W., Ding, S., \& Pickering, M. (2010). Integrating a personal and social responsibility program into a wellness course for urban high school students: Assessing implementation and educational outcomes. Sport, Education and Society, 15(3), 277298. doi: 10.1080/13573322.2010.493309

Yoder L. J. (1993). Cooperative learning and dance education. Journal of Physical Education, Recreation \& Dance 64(5), 47-56. doi:10.1080/ 07303084.1993 .10609977$.

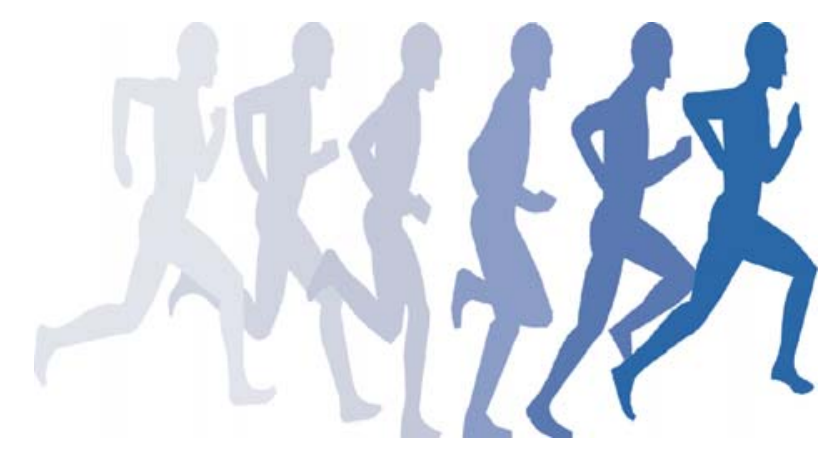

